\title{
Diversification Perspectives of a Single Equity Market: Analysis on the Example of Selected CEE Countries
}

\author{
Florin Aliu (iD https://orcid.org/0000-0002-4782-8820 \\ Assistant Professor, University for Business and Technology (UBT) \\ Faculty of Management, Business, and Economics, Prishtina, Kosovo \\ e-mail: florin.aliu@ubt-uni.net
}

\begin{abstract}
Fisnik Aliu (iD https://orcid.org/0000-0001-8886-6738
Computer Engineer, University for Business and Technology (UBT)

Faculty of Computer Science and Engineering, Prishtina, Kosovo

e-mail: fisnik.aliu@gmail.com
\end{abstract}

\begin{abstract}
Artor Nuhiu (iD) https://orcid.org/0000-0001-8239-1604
Assistant Professor, corresponding author, University of Prishtina, Faculty of Law

Prishtina, Kosovo, e-mail: artor.nuhiu@uni-pr.edu
\end{abstract}

\author{
Naim Preniqi (iD) https://orcid.org/0000-0001-6947-8043 \\ Professor, University for Business and Technology (UBT) \\ Faculty of Management, Business, and Economics, Prishtina, Kosovo \\ e-mail: naim.preniqi@ubt-uni.net
}

\section{Abstract}

The study addresses the benefits of a unified stock market in terms of diversification risk for the eight CEE stock markets. For this purpose, each stock market was treated as a separate portfolio based on the companies listed during 2018-2019. Portfolio diversification techniques were used to identify risk linked with the eight Central Eastern European stock markets. The results show that the stock market with the lowest diversification risk was the Bulgarian Stock Exchange, followed by the Prague Stock Exchange, the Ljubljana Stock Exchange, and at the end stands the Zagreb Stock Exchange. The portfolio constructed from the Zagreb Stock Exchange carries the highest portfolio risk, but it also offers the highest weekly weighted average returns. Stock 
markets that benefit in terms of portfolio risk from unification are the Bratislava Stock Exchange, the Budapest Stock Exchange, the Bucharest Stock Exchange, the Warsaw Stock Exchange, and the Zagreb Stock Exchange. The indexes where the portfolio risk increases at the time of unification are the Bulgarian Stock Exchange, the Ljubljana Stock Exchange, and the Prague Stock Exchange. From a managerial perspective, financial investors get a novel outlook on the diversification possibilities offered within a hypothetical unified CEE stock market.

Keywords: diversification opportunities, CEE stock market, unification benefits, risk-reward tradeoff

JEL: G11, G12

\section{Introduction}

Stock markets are an important indicator that generates signals in the current spark of the financial system and the economy in general. Efficient stock markets integrate overall information related to financial problems, political issues, natural disasters, and so on, into equity prices. The member states of the European Union (EU) hold different cultural backgrounds, languages, and political systems but act as a common economic unit. The single EU market, which represents the free movements of goods, services, people, and money, was followed by the common currency, the euro. Even though 19 member countries embraced the euro as the national currency, there are still differences over taxes, restructuring policies, and capital markets, among others. Euronext (2020) is an example where the stock markets of Paris, Amsterdam, London, Oslo, Milan, Dublin, and Lisbon operate under the rules of a joint institution.

The standard financial paradigms indicate that the unified equity market provides additional liquidity for listed firms, lower transaction costs, and offers higher visibility for international investors. Nielsson's (2009, pp. 229-267) study of Euronext shows that the biggest beneficiaries from the unified exchange were large, capitalized corporations, while for small and medium-size firms, the effect was insignificant. Another form of a common equity index is Nasdaq Baltic, which includes listed firms from Lithuania, Estonia, and Latvia (Nasdaq Baltic Equity Index 2020). Meanwhile, Bulgaria, Macedonia, and Croatia also set up a joint trading platform for equity stocks, named SEE link (2020). In principle, unifying equity markets enables low activity exchanges to increase their trading volume and reduce transaction costs. This is also in line with the European Commission directive "MiFID II," which seeks to increase transparency, unification, and better regulation of the European financial markets (European Commission 2014).

In August 2015, Jean-Claude Junker, president of the European Commission, launched initiatives on the conceptual economic benefits of a Capital Markets Union (CMU) (Juncker 2014). The idea was to create a single capital market for all European 
Union countries by the end of 2019. The work by Quaglia, Howarth, and Liebe (2016, p. 185) found that a CMU would reduce fragmentation of financial markets in EU countries, create new financing channels for firms, and encourage cross borders capital movements. Establishing a CMU would enhance cross-border financial integration, which relies on information transparency and data reliability to reduce information asymmetry (Véron and Wolff 2016, pp. 130-153).

In Central and Eastern European (CEE) countries, banks play a crucial role in financing business needs and human consumption. Corporations in these countries prefer to finance their liquidity and investment projects through banking channels rather than the capital markets. People in Europe keep their savings mainly as bank deposits, while in the US, they are in the form of financial securities. Stock markets in CEE countries are characterized by a small number of listed firms and limited trade volume. Speculative stock prices are additional problems that prevent the efficient functioning of capital markets in CEE countries. The study by Miloş, Barna, and Boțoc (2020, p. 535) of seven CEE stock markets (including those in our study) indicated that stock prices do not follow a random walk, which violates the efficient market hypothesis (EMH). Other authors confirm the inefficiency of CEE stock markets by covering the problem on different time intervals and different countries (Nivet 1997, pp. 171-183; Ajayi, Mehdian, and Perry 2004, pp. 53-62; Worthington and Higgs 2004, pp. 59-78; Guidi, Gupta, and Maheshwari 2011, pp. 337-389).

The inefficiency of the equity markets generates stock prices that do not reflect the domestic and international economic reality. Since not all events are integrated into stock prices under an inefficient market, this creates information asymmetry and prevents potential trades. The possibility of creating a joint-stock market for CEE countries would increase liquidity, efficiency, and attention from international investors. Obstacles with unifying stock markets in these countries might be related to national accounting systems, monetary policies (for non-eurozone countries), different taxation, and unique political systems.

The purpose of this study was to identify the diversification benefits of a single equity market for the selected CEE countries, although the issue of creating a single equity market in CEE countries exceeds the remit of this study. The issue of a single market involves difficulties related to political will, taxation systems, monetary policies, and trading platforms, among others. Recognizing the importance of creating a single equity market in Europe, the theoretical contribution of this study appears in two dimensions. First, in the use of portfolio techniques in measuring diversification risk of a possible single equity market in CEE countries. Second, it verifies the well-established portfolio theory that increasing the number of stocks decreases the divarication risk of the portfolio.

The study contributes to the ongoing discussion of the European Commission on the unification of capital markets (bond and equity exchanges). The idea of a single capital market is a very complex topic that requires addressing the problem from different perspectives. CEE countries have experienced almost identical economic and 
political transitions. Considering the common features of CEE countries, our work provides a financial perspective on the possibility of a unified equity market. The study investigates the risk-reward relationships of merging the seven stock markets of CEE countries. From the complexity of this process, the results analyze diversification risk attached to the separate stock markets of CEE countries. First, the study compares diversification risk and weekly weighted average returns for selected stock exchanges of CEE countries. Generating a unified stock market does not necessarily provide higher diversification benefits for all analyzed stock markets.

\section{Literature review}

Constructing an optimal portfolio is a task that requires continuous commitments as the market dynamics constantly change. The financial meltdown of 2008/2009 and the Greek debt crisis of 2010/2011 proved that the world financial system is highly integrated. Financial globalization, together with international trade, means that the benefits of international diversification exist on a limited scope (Driessen and Laeven 2007, pp. 1693-1712). Publicly listed companies are located in different countries where their sales tend to be well-diversified. A series of studies show the possibilities of reaching full diversification by investing only in local publicly listed companies (Errunza, Hogan, and Hung 1999, pp. 2075-2107; Aliu et al. 2019, pp. 273-287; Berrill, Kearney, and O'Hagan-Luff 2019, pp. 672-684).

The stock exchanges of Eastern European Countries have different levels of efficiency, and therefore, they are at different stages of diversification. Aliu et al. (2019, pp. 273287), using portfolio diversification techniques, believed that the Budapest Stock Exchange (BUX) offers higher diversification benefits than the Warsaw Stock Exchange (WIG20) and the Bratislava Stock Exchange (SAX). Equity markets tend to be highly interconnected in times of crisis, while in normal periods, each stock exchange follows its course. A recent study by Tilfani, Ferreira, and El Boukfaoui (2020, pp. 643-674) showed that the stock markets of the Czech Republic, Hungary, Poland, Croatia, and Romania are highly interconnected in the short run. However, stock markets with limited trade volumes and efficiency, like those of Slovakia, Serbia, and Bosnia, tend not to show signs of integration. Meanwhile, Boţoc and Anton (2020) indicated that CEE stock markets hold short and long-run co-integration with the stock markets of Germany, the UK, and the USA.

The concept of a common European market and the introduction of a single currency (the euro) have diminished the fragmentation of financial markets in eurozone countries. The interdependence within the stock markets of Eastern European countries with Western ones reduces the diversification opportunities for international investors.

The number of financial assets within a portfolio affects the diversification risk by reducing or increasing the concentration level. Scholars and practitioners still have 
not reached a consensus on the number of shares that would fully eliminate portfolio risk. An earlier study by Evans and Archer (1968, pp. 761-767) showed that a portfolio containing 8 to 16 shares achieves maximum diversification benefits. In measuring portfolio risk, scholars use various diversification techniques at different time intervals and geographical locations. Increasing the number of shares in the portfolio from 1 to 10 reduces the portfolio risk by $50 \%$, while moving from 10 to 20 shares, the risk declines by only 5\% (Elton and Gruber 1977, pp. 415-437). However, Statman (1987, pp. 353-363) found that portfolios constructed with 30 to 40 equity stocks manage to reduce portfolio risk significantly.

Aliu et al. (2020, pp. 41-51) recently investigated diversification benefits using weekly data from companies listed in the six largest European stock exchanges. The results show that diversification risk begins to be eliminated when the portfolio contains more than 47 stocks. Correlation among assets in the portfolio is an additional component of portfolio risk. A higher positive correlation among the financial assets increases the portfolio risk, and vice versa. Thus, portfolio managers tend to find financial assets that are not correlated to each other or stay in the negative correlation zone. Although within the financial system, it is difficult to find securities that hold a negative correlation. However, correlation identifies short-run dependency among securities while the co-integration method follows this phenomenon in the long run.

Knowledge of financial instruments directly affects portfolio optimization and the diversification level. Çera et al. (2020, pp. 1-18) found that financial literacy can be improved by carefully informing individuals about financial products and their importance, whereby their financial behavior can be rationalized. Abreu and Mendes (2010, pp. 515-528), using a 2007 survey from UniCredit customers, investigated financial literacy for investors regarding their portfolio choices. Based on the survey, the lack of proper diversification is related to financial literacy by the investors. Financial literacy is based on the knowledge and experience of individuals to effectively manage their finances.

Moreover, the level of education, cultural characteristics, demographic structure of the population, and technological advancement are factors that affect the level of financial literacy. Individuals tend to invest in only a few stocks and are not diversified, as they place their money in the firms they work with (Dorn and Huberman 2005, pp. 437-481). A lack of regional and global diversification of the individual's wealth is linked to the fact that they are more focused on the local companies (Moskowitz and Vissing-Jørgensen 2002, pp. 745-778). However, there is ample evidence that sustainable diversification benefits can be achieved by investing in local companies that operate internationally (Errunza, Hogan, and Hung 1999, pp. 2075-2107; Aliu et al. 2019, pp. 273-287; Berrill, Kearney, and O’Hagan-Luff 2019, pp. 672-684).

In the 1990s, most CEE countries went from a command economy to a system where prices are set by market forces. However, a free-market economy and well-organized financial markets are concepts not well known to these countries. According to the Central Bank of Slovakia (2019), financial literacy may be one of the reasons why peo- 
ple are dissatisfied with the services of the financial system. Beckmann (2013, p. 9) showed that in Romania, savings and investments are positively related to the level of financial literacy. Adequate knowledge of the financial system and personal finances enables individuals to react rationally in certain situations. Klapper, Lusardi, andPanos (2013, pp. 3904-3923) investigated issues related to financial literacy in Russia, where there has been an enormous increase in the debt of private individuals.

Despite the benefits offered by stock market unification, it is extremely complex, involving not only economic issues but also political will. Brexit has made this problem even more difficult, as London (The City) was the main financial center in the European Union. Portfolio diversification techniques were used to explore the possibility of creating a single equity market for CEE countries. Seven equity markets have been selected from CEE countries to measure their risk and identify the benefits of the unified exchange. Our study deals only with equity markets in the CEE countries, bypassing the bond market, which is even more complex when analyzed. First, the study divides the selected stock exchanges into separate portfolios based on the number of listed firms during 2018 and 2019. The additional aim of the study was to identify which countries benefit from a unified equity market in terms of diversification risk and which do not. Based on the identified problem, the following questions were asked:

$R Q 1$ : Which is the individual diversification risk of a selected CEE equity exchange?

RQ2: Which are the diversification benefits of a unified CEE equity exchange for individual countries?

\section{Methodology}

The methodology is organized into two sections, where section 3.1 analyzes data collection while section 3.2 focuses on the diversification model.

\section{Data collection and processing}

The study measures the risk and returns tradeoff of the individual CEE stock markets and identifies the diversification benefits of unified stock markets in terms of risk and rewards. Closed stock prices and trading volume were the two main inputs used in the diversification model. Table 1 shows the selected equity exchanges for our study, the number of firms, and the period when the data were analyzed. Stock prices and trading volume were collected weekly from 5.01.2018 to 3.01.2020 for individual firms listed.

Seven CEE stock markets were selected, i.e., the Bratislava Stock Exchange (SAX), Budapest Stock Exchange (BUX), Prague Stock Exchange (PSE), Warsaw Stock Exchange (WIG20), Bucharest Stock Exchange (BVB), Zagreb Stock Exchange (ZSE), Ljubljana Stock Exchange (LJSE), and Bulgarian Stock Exchange (BSE). 
Table 1. Stock exchanges of CEE countries and the number of firms selected

\begin{tabular}{|l|l|l|c|c|}
\cline { 2 - 5 } \multicolumn{1}{c|}{} & \multicolumn{1}{c|}{ Equity Index } & \multicolumn{1}{c|}{ Country } & No. of firms & \multicolumn{1}{c|}{ Period } \\
\hline Portfolio A1 & SAX & Slovakia & 7 & $5.01 .2018-3.01 .2020$ \\
\hline Portfolio A2 & BUX & Hungary & 14 & $5.01 .2018-3.01 .2020$ \\
\hline Portfolio A3 & PSE & Czech Republic & 12 & $5.01 .2018-3.01 .2020$ \\
\hline Portfolio A4 & WIG20 & Poland & 20 & $5.01 .2018-3.01 .2020$ \\
\hline Portfolio A5 & BVB & Rumania & 14 & $5.01 .2018-3.01 .2020$ \\
\hline Portfolio A6 & ZSE & Croatia & 18 & $5.01 .2018-3.01 .2020$ \\
\hline Portfolio A7 & LJSE & Slovenia & 10 & $5.01 .2018-3.01 .2020$ \\
\hline Portfolio A8 & BSE & Bulgaria & 14 & $5.01 .2018-3.01 .2020$ \\
\hline Portfolio C & (SAX + BUX + PSE + WIG20 + & - & 109 & $5.01 .2018-3.01 .2020$ \\
& + BVB + ZSE + LJSE + BSE) & & & \\
\hline
\end{tabular}

Source: authors' own elaboration.

In financial markets, we have continuous entry and exit of firms, which affects the structure of the exchange. For this reason, only firms were used that have closed prices and trade volume in the Thomson Reuters Eikon Database (2020), from 5.01.2018 to 3.01.2020. The closed stock prices and trade volume for all selected companies are harmonized on identical dates. Each stock market is considered a separate portfolio based on the number of firms listed during the period covered in our study. Portfolio A1 stands for the Slovak Stock Market (SAX), portfolio A2 for the Hungarian Stock Market (BUX), and so on, to portfolio A8 linked to the Bulgarian Stock Market (BSE). However, portfolio C represents the unification of the eight stock markets selected for our study (SAX + PSE + WIG20 + BVB + ZSE + LJSE + BSE). Countries like Poland, Romania, Hungary, Bulgaria, Croatia, and the Czech Republic have their national currencies, while Slovenia and Slovakia use the euro. To harmonize the data in portfolio $C$, stock prices and trade volume of all firms from the TRD were collected in the euro currency. The work does not consider the exchange rate risk, direct and indirect taxes, or transaction costs.

\section{Diversification model}

Since stock markets are classified as separate portfolios, their risk is measured using Markowitz's (1952) diversification techniques. Diversification risk is influenced by elements such as correlation among financial instruments, concentration, and volatility of returns. When the concentration level (measured by trade volume) in the portfolio increases, the diversification risk is higher and vice versa. An additional element of portfolio risk is correlation among assets, standing between -1 and +1 $\left(-1 \leq \varphi_{\mathrm{ij}} \leq+1\right)$. Portfolio managers reduce portfolio risk when items are not perfectly positively correlated. However, in reality, it is very difficult to combine assets that have perfect negative correlation -1 . The formula below presents the correlation coefficient: 


$$
\varphi_{1,2}=\frac{\operatorname{cov}(1,2)}{\sigma_{1} \sigma_{2}}
$$

where: cov stands for the covariance between two securities $(1,2)$, and $\sigma_{1}$ and $\sigma_{2}$ indicate the standard deviation of the first and second security in the portfolio. Portfolio uncertainties also depend on the standard deviation of each financial asset found in the portfolio. The standard deviation is measured by the weekly returns of each stock identified in the respective portfolios (portfolio A1, A2, .., A8, C). Markowitz's diversification formula is used to measure the diversification risk of the separate portfolios selected for our study. The general form of the diversification risk formula is as follows:

$$
\operatorname{Pr}_{k}^{2}=\sum_{i}^{n_{k}} w_{i_{k}}^{2} \sigma_{i_{k}}^{2}+2 \sum_{i}^{n_{k}} \sum_{j<i}^{n_{k}} w_{i_{k}} w_{j_{k}} \sigma_{j_{k}} .
$$

Explanations regarding the formula used: The method indicates that $P r_{k}^{2}$ stands for the portfolio in the year $\mathrm{k}$ and is calculated based on the number of $n_{k}$ listed firms. Items such as $i, j=1, \ldots, n_{k}$ show the positions and order of the companies in the particular portfolios (stock markets); basically, index $i$ and $j$ stand for the listed firms. Item $i$ is linked with a particular security (listed firm), while item $j$ assures that correlations are generated on distinct assets in the portfolio. However, $w$ captures the weights of the assets (stock market firms) in the portfolio while $w^{2}$ stands for the squared weights. $\sigma^{2}$ represents the variance of returns while $\sigma$ indicates the standard deviation of returns of individual securities in the portfolio. $\varphi_{(i, j)}$ represents the correlation coefficient of all possible firms in the portfolios (stock markets).

The programs that are used to implement the diversification risk formula are Python 3.6.3 (version 0.21.0), Jupiter Notebook (version 5.2.0), and Numpy (version 1.13.3). The equation below is used to generate the results for the inputs used in our study:

$$
\mathrm{U}_{\mathrm{ij}}=\left\{\begin{array}{cc}
\mathrm{b}_{\mathrm{ij}} & \text { for } i<j \\
0 & \text { for } i \geq j
\end{array}\right.
$$

where: $b_{i j}$ shows the orders (sequences) among listed firms in the portfolio, $i$, and $j$. The first step in the process is to organize the excel table with all possible combinations between financial securities (in our case, equity stocks). This process involves combinations with $1,2,3,4,5,6, \ldots \ldots \ldots . n$ where $n$ indicates all the equity stock within the experiment. The combinations could be between "Equity Stock A" and "Equity Stock B," while the other combination might be within "Equity Stock A," "Equity Stock B," and "Equity Stock C". Combinations of the financial securities in the organized table generate merging data, where the merging happens by grouping financial securities of each stock market in one place. The identical process of merging data 
tracked all selected equity indexes (in our case, named portfolio A1, A2 .......). For the combination process and merging the data, the panda library was used. (A special program is built for this whole process and is available on request.)

The next step requires cleaning the data for all files that are generated from the combinations of the financial securities. Rows were removed for all equity stocks that did not have data for the period we have defined. To make the best use of the data, the interpolation method was used for the missing data. The final procedure contains the calculation of all combinations for each portfolio (A1, A2 ....., C). Each portfolio is driven through the calculated inputs such as "Correlation," "Variance," "Standard Deviation," and "Portfolio Risk".

Returns to investors are generated from price changes (capital gains or losses) and the level of dividends distributed. The study does not take into account the level of dividend distributed but measures only weekly weighted average returns. The reason why weighted average returns are selected and not a simple arithmetic return is because companies have different weights within their portfolios (stock markets). The formula below shows the weighted average returns:

$$
\text { war }=\sum_{i=1}^{n} w_{i} R_{i}
$$

A higher concentration of securities within the portfolio increases the diversification risk and vice versa. The Herfindahl-Hirschman Index (HHI) is used to measure the concentration level via trade volume that each firm contains within its respective portfolios. Portfolios containing HHI less than 1500 points are considered sufficiently competitive, while portfolios with HHI between 1500 and 2500 points are considered moderately concentrated. However, HHI over 2500 points is treated as highly concentrated, where two or three companies hold most of the trading volume in the portfolio. The formula below shows how $\mathrm{HHI}$ is calculated:

$$
\mathrm{HHI}=f_{1}^{2}+f_{2}^{2}+f_{3}^{2}+f_{4}^{2}+\ldots \ldots \ldots \ldots f_{n}^{2},
$$

where: $f_{n}$ represents the percentage share of firm $n$ within the portfolios (stock market), which appears as an integer and not a percentage.

\section{Results}

The results are divided into two parts. Section 4.1 compares the diversification risk of individual stock markets (portfolios), while section 4.2 identifies the diversification benefits of a unified CEE stock market. 


\section{Diversification risk of the individual portfolios (stock markets)}

The work analyzes the risk-return tradeoff of each portfolio based on the Markowitz diversification techniques. Stock markets selected from the CEE countries are considered separate portfolios based on the listed firms during 2018/2019. Table 2 shows the descriptive statistics for the eight selected stock markets analyzed in our study.

Table 3 shows the main inputs used to measure portfolio risk $(\operatorname{Pr})$, such as weight concentration (HHI), average correlation $\left(\rho_{i j}\right)$, average variance $\left(\sigma^{2}\right)$, and average standard deviation of returns $(\sigma)$. The HHI shows that five portfolios are highly concentrated, i.e., portfolio A1 $(\mathrm{HHI}=6626.5)$, followed by portfolio A5 $(\mathrm{HHI}=4971.3)$, portfolio A7 (HHI = 4314.1), portfolio A3 (HHI = 4138.8), and portfolio A6 $(\mathrm{HHI}=3298.2)$. The BSE index, i.e., portfolio A8, has a moderate degree of concentration, where HHI is 1571 . Portfolios C, A4, and A2 are sufficiently competitive, with HHI lower than 1500 points. Portfolio A1 (SAX) holds the highest level of concentration, while portfolio $\mathrm{C}$ (hypothetical CEE Index) holds the lowest.

Table 4 indicates the correlation matrix of the companies listed on the Prague Stock Exchange (PSE) - portfolio A3. On average, all portfolios contain a positive correlation (Avg. $\rho_{i j}$ ), increasing portfolio risk $(\operatorname{Pr})$. The lowest average positive correlation is for portfolio A7 ( $\left.\varphi_{i j}=+0.03\right)$, tracked by portfolio A1 $\left(\varphi_{i j}=+0.04\right)$, portfolio C and $\mathrm{A} 6\left(\varphi_{i j}=+0.05\right)$, while portfolio A5 $\left(\varphi_{i j}=+0.39\right)$ is at the end.

The Ljubljana Stock Exchange (LJSE), i.e., portfolio A7, holds the lowest positive average correlation, while the Bucharest Stock Exchange (BVB), i.e., portfolio A5, has the highest positive average correlation. Uncertainties created by price changes are an additional element that influences portfolio risk $(\mathrm{Pr})$. The average standard deviation (Avg. $\sigma$ ) is measured by the weekly returns of each firm listed in the respective portfolios. The index with the highest degree of volatility is portfolio A7 ( $\sigma=5.5 \%$ ), followed by portfolio A6 ( $\sigma=4.3 \%)$; portfolio A3 $(\sigma=2.4 \%)$ has the lowest volatility level. 
Diversification Perspectives of a Single Equity Market...

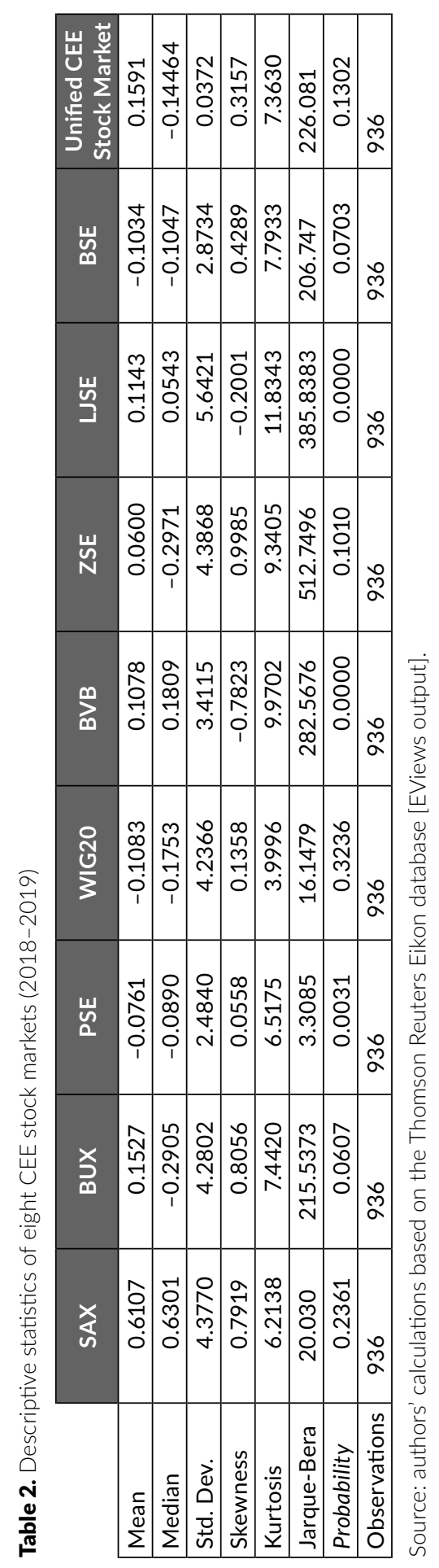


Florin Aliu, Fisnik Aliu, Artor Nuhiu, Naim Preniqi

Table 3. The main components used for measuring portfolio risk ( $P r)$

\begin{tabular}{|l|l|c|c|c|c|c|c|}
\cline { 2 - 8 } \multicolumn{1}{c|}{} & \multicolumn{1}{c|}{ Indexes } & HHI & Pr & Avg. $\sigma$ & Avg. $\sigma_{i j}$ & Avg. $\sigma^{2}$ & war \\
\hline Portfolio A1 & SAX & 6626.5 & $2.7 \%$ & $3.4 \%$ & 0.04 & 0.00354 & -0.12 \\
\hline Portfolio A2 & BUX & 1290.9 & $2.3 \%$ & $4.2 \%$ & 0.11 & 0.00248 & 0.41 \\
\hline Portfolio A3 & PSE & 4138.8 & $1.7 \%$ & $2.4 \%$ & 0.14 & 0.00065 & 0.02 \\
\hline Portfolio A4 & WIG20 & 1183.4 & $2.5 \%$ & $4.2 \%$ & 0.25 & 0.00185 & -0.22 \\
\hline Portfolio A5 & BVB & 4971.3 & $2.9 \%$ & $3.3 \%$ & 0.39 & 0.00121 & 0.39 \\
\hline Portfolio A6 & ZSE & 3289.2 & $5.5 \%$ & $4.3 \%$ & 0.05 & 0.00246 & 0.64 \\
\hline Portfolio A7 & LJSE & 4314.1 & $1.9 \%$ & $5.5 \%$ & 0.03 & 0.00495 & 0.07 \\
\hline Portfolio A8 & BSE & 1571.2 & $1.4 \%$ & $2.8 \%$ & 0.06 & 0.00096 & -0.05 \\
\hline Portfolio C & CEE index & 951.1 & $2.1 \%$ & $3.7 \%$ & 0.05 & 0.00169 & 0.07 \\
\hline
\end{tabular}

Source: authors' own elaborations based on the Thomson Reuters Eikon Database (2020).

Portfolio A6 ( $P r=5.5 \%$ ) has the highest level of diversification risk, followed by portfolio A5 $(\operatorname{Pr}=2.9 \%)$, portfolio A1 $(\operatorname{Pr}=2.7 \%)$, and finally portfolio A8 $(\operatorname{Pr}=1.4 \%)$. The lowest level of portfolio risk is generated by the Bulgarian Stock Exchange (BSE), i.e., portfolio A8. In contrast, the Zagreb Stock Exchange (ZSE) - portfolio A6 - holds the highest level of portfolio risk ( $P r=5.5 \%)$, but it also offers the highest weekly weighted average return $($ war $=0.64)$. 
Diversification Perspectives of a Single Equity Market...

\begin{tabular}{|c|c|c|c|c|c|c|c|c|c|c|c|}
\hline$\exists$ & & & & & & & & & & & $\rightarrow:$ \\
\hline 으 & & & & & & & & & & $\rightarrow$ & 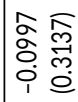 \\
\hline$a$ & & & & & & & & & $\rightarrow$ & 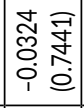 & 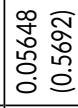 \\
\hline$\infty$ & & & & & & & & $\rightarrow$ & 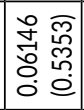 & 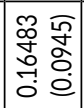 & 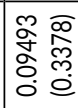 \\
\hline$r$ & & & & & & & $\rightarrow$ & 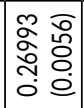 & 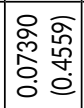 & 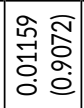 & 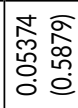 \\
\hline 0 & & & & & & $\rightarrow$ & 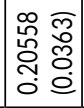 & 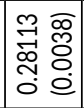 & 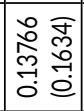 & 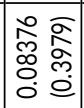 & 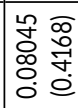 \\
\hline in & & & & & $\rightarrow$ & 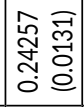 & 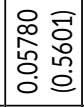 & 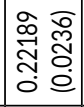 & $\begin{array}{ll}0 & \overline{0} \\
o & 0 \\
\stackrel{0}{0} & 0 \\
0 & 0 \\
0\end{array}$ & 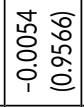 & 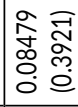 \\
\hline$\nabla$ & & & & $\rightarrow$ & 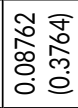 & 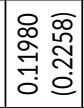 & 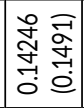 & 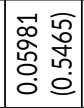 & 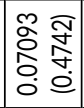 & 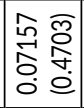 & 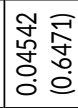 \\
\hline$m$ & & & $\rightarrow$ & 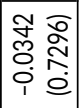 & 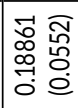 & 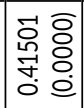 & 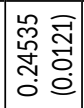 & 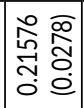 & 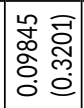 & 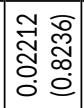 & 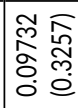 \\
\hline$\sim$ & & $\rightarrow$ & 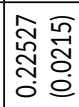 & 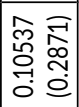 & 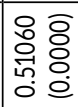 & 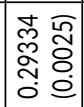 & 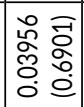 & $\begin{array}{l}\text { ơ } \\
\text { 心 } \\
\text { ơ } \\
\text { ơ } \\
0\end{array}$ & 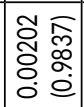 & 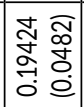 & 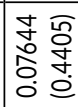 \\
\hline$\rightarrow$ & $\rightarrow$ & 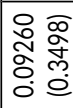 & 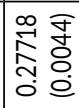 & 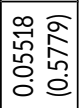 & 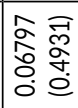 & 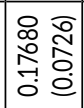 & 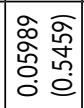 & 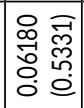 & 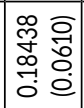 & 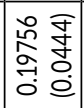 & 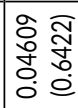 \\
\hline 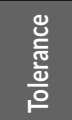 & 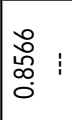 & 㷉 & $\mid$ & 旁： & 离: & 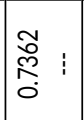 & 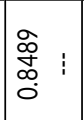 & $\mid \begin{array}{l}\mathscr{O} \\
\stackrel{\infty}{\infty} \\
\stackrel{0}{0}\end{array}$ & $\mid \begin{array}{ll}\infty & \\
\stackrel{2}{a} & \vdots \\
O & \vdots\end{array}$ & 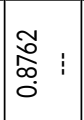 & $\mid$ \\
\hline 岇 & 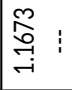 & 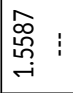 & 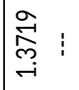 & $\begin{array}{l}\hat{\widehat{\alpha}} \\
\text { Oे } \\
\stackrel{-}{-}\end{array}$ & 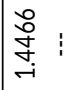 & 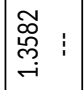 & 奈: & $\mid$ & 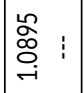 & 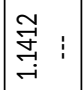 & 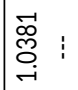 \\
\hline 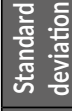 & 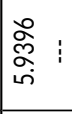 & 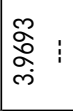 & $\mid$ & 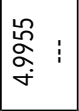 & 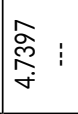 & $\mid \begin{array}{ll}\infty & \\
\infty & \\
\infty & \vdots \\
\infty & \vdots \\
\sim & \end{array}$ & $\mid \begin{array}{l}\stackrel{0}{ } \\
\stackrel{2}{*} \\
\text { in } \\
\text { in }\end{array}$ & 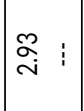 & 㝵: & 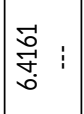 & 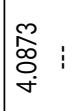 \\
\hline 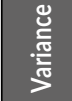 & 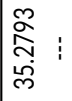 & 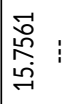 & 空 & 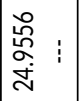 & 突 & 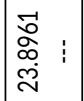 & 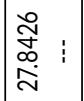 & \begin{tabular}{|l|} 
\\
\multirow{2}{*}{} \\
$\infty$ \\
$\infty$ \\
$\infty$
\end{tabular} & 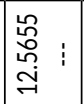 & 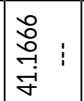 & 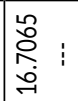 \\
\hline & 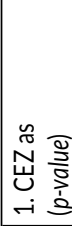 & 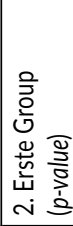 & 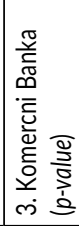 & 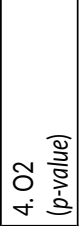 & 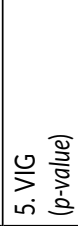 & 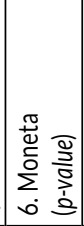 & 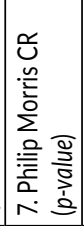 & 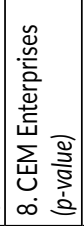 & 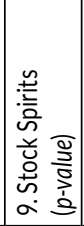 & 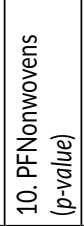 & 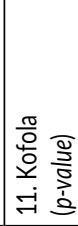 \\
\hline
\end{tabular}




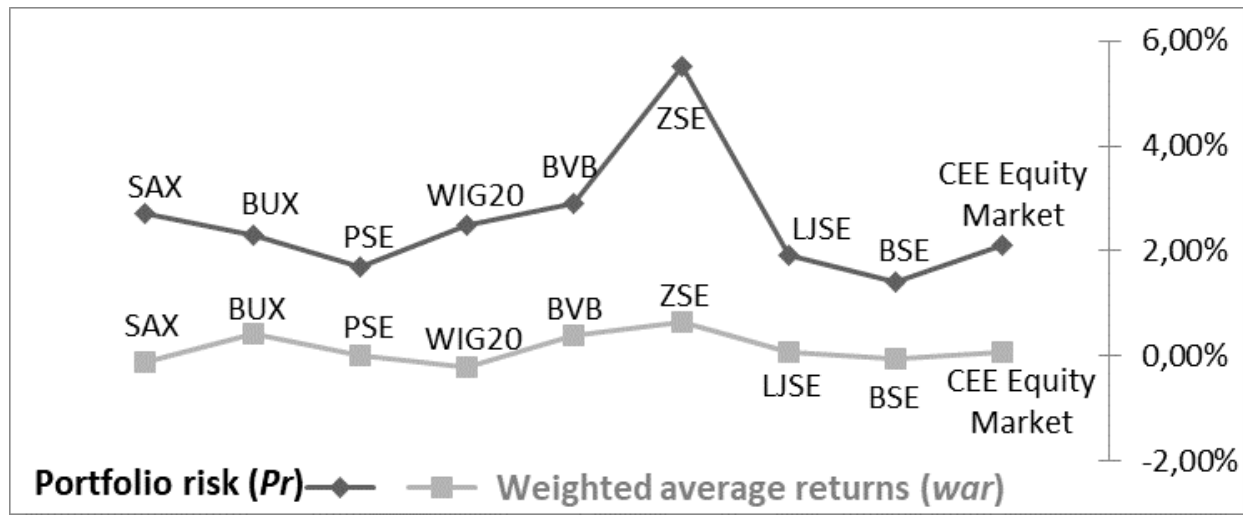

Chart 1. The relationship between weekly weighted average returns (war) and portfolio risk ( $\mathrm{Pr})$ Source: authors' calculations based on the Thomson Reuters Eikon Database (2020).

Chart 1 shows the relationship between portfolio risk $(P r)$ and the weekly weighted average return (war) of the selected portfolios. The graph indicates that the relationship between risk and return in most portfolios is in line with portfolio theories (the risk level is offset by return benefits). Switching from BUX to PSE, the portfolio risk decreases, but the weekly weighted average returns. In contrast, if we move from PSE to WIG20, the portfolio risk increases and the returns fall; the same happens with SAX. The exception is ZSE, where the higher portfolio risk is not offset by the same increase in the weekly weighted average returns. The portfolios where the risk-return tradeoff is in line with portfolio theories are BUX, PSE, BVB, LJSE, BSE, and the hypothetical CEE Index. Meanwhile, portfolios that go against portfolio theories are ZSE and SAX.

\section{Diversification benefits of a unified hypothetical CEE equity index}

This section analyzes the benefits of a unified stock market in terms of portfolio risk, volatility, weekly weighted average returns, and concentration level. As can be seen from Chart 2, some countries benefit from stock market unification while others do not. Countries that benefit in terms of portfolio risk $(\mathrm{Pr})$ from the stock market unification are portfolios A1 (SAX), A2 (BUX), A4 (WIG20), A5 (BVB), and A6 (ZSE). Portfolio $C$ is $10 \%$ less risky than A2, 19\% less risky than A4, 29\% less risky than $\mathrm{A} 1,38 \%$ less risky than $\mathrm{A} 4$, and $162 \%$ less risky than A6. In contrast, portfolios that do not benefit from the stock market unification are A8 (BSE), A7 (LJSE), and A3 (PSE). However, portfolio $\mathrm{C}$ is $10 \%$ riskier than A7, 19\% riskier than A3, and 33\% riskier than A8. 


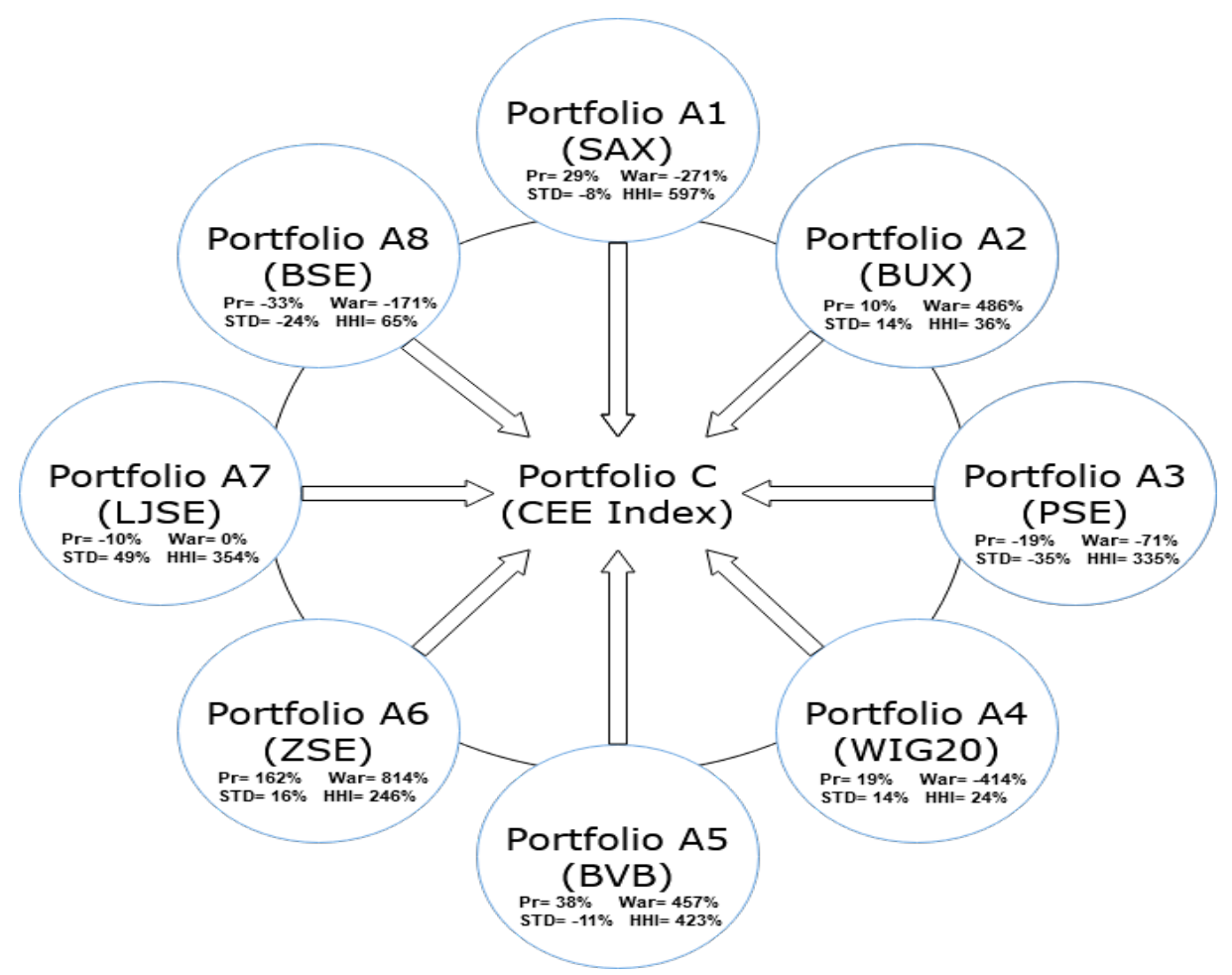

Chart 2. The benefits of a common equity index in terms of risk, returns, volatility, and concentration level

Source: authors' calculations based on the Thomson Reuters Eikon Database (2020).

Analyzing the weekly weighted average returns, three portfolios will realize higher weekly weighted average returns while the other three will have lower weekly weighted average returns from unification. Portfolios that might enjoy higher weekly weighted average returns from unification are A8 (BSE), A4 (WIG20), and A1 (SAX). In contrast, portfolios like A2, A5, and A6 do not benefit from unification since they already hold better returns than the hypothetical portfolio C. Portfolio A7 (LJSE) has identical weighted average weekly returns with portfolio C.

Portfolios that benefit from the unification of stock markets in terms of the standard deviation of returns (STD) are A1, with an $8 \%$ decrease in STD, A5, with an $11 \%$ decrease, A8 with 24\%, and A3 with 35\%. In contrast, portfolios that do not benefit from the unified stock market in terms of STD are portfolios A2, A4, A6, and A7. The level of concentration measured via the HHI Index declines for all selected stock markets when pooled into a single equity market. 
Table 5. The weights of the largest companies in their national indexes and within the hypothetical CEE index

\begin{tabular}{|l|c|c|}
\hline \multicolumn{1}{|c|}{ Company Names } & Weights (portfolios) & Weights (CEE exchange) \\
\hline Tatry Mountain Resorts as (SAX) & $80.50 \%$ & $1.32 \%$ \\
\hline Opus Global Nyrt (BUX) & $16.20 \%$ & $1.51 \%$ \\
\hline Moneta Money Bank as (PSE) & $61.80 \%$ & $2.70 \%$ \\
\hline Tauron Polska Energia SA (WIG20) & $22.80 \%$ & $11.60 \%$ \\
\hline OMV Petrom SA (BVB) & $64.20 \%$ & $22.20 \%$ \\
\hline OT Optima Telekom dd (ZSE) & $52.10 \%$ & $0.15 \%$ \\
\hline Krka dd Novo Mesto (LJSE) & $59.40 \%$ & $3.11 \%$ \\
\hline Industrial Holding Bulgaria AD (BSE) & $27.60 \%$ & $0.11 \%$ \\
\hline
\end{tabular}

Source: authors' calculations based on the Thomson Reuters Eikon Database (2020).

Table 5 shows that some companies lose their weights from the stock market unification. Moneta Money Bank's market position drops from $61.8 \%$ to $2.7 \%$ within the CEE index. The market position (weights) of Polish company Tauron Polska Energia declines from $22.8 \%$ to $11.6 \%$ during the transition to the hypothetical CEE equity market. In this aspect, a common CEE equity market is not in favor of companies listed on the national stock markets, as they lose their visuality from the unification process.

\section{Conclusion}

Capital markets are an important pillar for generating a competitive environment within the financial system. The stock markets of CEE countries are characterized by a low level of efficiency, which indicates that not all events are integrated into stock prices. Unification might increase trade volume, harmonize transaction costs, and eventually increase the efficiency of CEE equity markets. This paper compares risk returns tradeoffs based on the diversification techniques related to the selected CEE stock markets. The study also analyzed which countries benefit and which do not in terms of diversification risk from the stock market unification. Selected equity markets are considered as separate portfolios based on the listed firms during 2018 and 2019. Based on the HHI, eight portfolios have a high concentration level where a limited number of firms influence the entire stock market performance. The unified hypothetical CEE equity market reduces the concentration of all selected exchanges but diminishes the importance of large companies.

The correlations between assets influence portfolio risk, where the BVB Index has the highest average positive correlation while the LJSE has the lowest. In terms of volatility, the LJSE Index shows the highest level of STD while the PSE Index has the lowest.

The first research question addressed the separate portfolio risk of the eight selected CEE equity markets. In response to the first research question, the index with the 
highest portfolio risk is ZSE, followed by BVB, SAX, and finally BSE Index. However, while the ZSE Index has the highest portfolio risk, it also offers the highest weekly weighted average returns.

The second research question raised the issue of diversification benefits from a single equity market for the selected CEE countries. Portfolio C, i.e., the hypothetical CEE equity market, does not reduce the portfolio risk of the overall selected exchanges. Therefore, after stock market unification, the portfolio risk increases for some countries while it decreases for others. The equity exchanges that benefit from unification in terms of portfolio risk are SAX, BUX, WIG20, BVB, and ZSE. However, for equity exchanges where the portfolio risk increases from unification are BSE, LJSE, and PSE. The increase in the size of the stock market generated by the unification may reduce its volatility. For some indexes, such as BUX, WIG20, ZSE, and LJSE, volatility increases from the unified stock market. However, the unified CEE index eliminates the important position of many listed firms that hold on to their national stock markets.

The results contribute to the ongoing discussion on the EU's capacity to create a single equity market. However, the results are limited solely to the risk-return tradeoffs of a possible common equity market in the selected CEE countries.

The complexity of stock market unification in CEE countries is also related to different transaction costs and diverse financial reporting standards. Furthermore, some of the member countries have national currencies and unique taxation systems that are not covered in our study. The results include only data for 2018 and 2019; to have a better understanding of risk outcomes, it would be preferable to compare historical trends. Stock market unification cannot be viewed only in terms of economic benefit, but also the cultural context and political differences. Moreover, stock markets are symbols of the national economy, which can hardly be merged under a unified, organized exchange. The European Commission's idea to operate within a unified capital market is an ambitious project that requires a more integrated approach to the problem and not just a financial one.

\section{References}

Abreu, M., Mendes, V. (2010), Financial literacy and portfolio diversification, "Quantitative Finance”, 10 (5), pp. 515-528, https://doi.org/10.1080/14697680902878105

Ajayi, R.A., Mehdian, S., Perry, M.J. (2004), The day-of-the-week effect in stock returns: further evidence from Eastern European emerging markets, "Emerging Markets Finance and Trade", 40 (4), pp. 53-62, https://doi.org/10.1080/1540496X.2004.1105 2582

Aliu, F., Krasniqi, B., Knapkova, A., Aliu, F. (2019), Interdependence and risk comparison of Slovak, Hungarian, and Polish stock markets: Policy and managerial implications, "Acta Oeconomica", 69 (2), pp. 273-287, https://doi.org/10.1556/032.2019 .69 .2 .6 
Aliu, F., Nuhiu, A., Krasniqi, B., Aliu, F. (2020), Modeling the Optimal Portfolio: The Case of the Largest European Stock Exchanges, "Comparative Economic Research. Central and Eastern Europe”, 23 (2), pp. 41-51, https://doi.org/10.18778/1508-2008 .23 .11

Beckmann, E. (2013), Financial literacy and household savings in Romania, "Numeracy", 6 (2), https://doi.org/10.5038/1936-4660.6.2.9

Berrill, J., Kearney, C., O'Hagan-Luff, M. (2019), Measuring the diversification benefits of investing in highly internationalized firms, "International Business Review", 28 (4), pp. 672-684, https://doi.org/10.1016/j.ibusrev.2019.01.005

Boţoc, C., Anton, S.G. (2020), New empirical evidence on CEE's stock markets integration, “The World Economy", 42 (10), pp. 2785-2802, https://doi.org/10.1111/tw ec. 12961

Central Bank of Slovakia (2019), The financial literacy support strategy of Narodna Banka Slovensko, https://www.nbs.sk/_img/Documents/_TS/191107/final_nbs_strategi aFinGram_en.pdf (accessed: 25.11.2020).

Çera, G., Khan, K.A., Mlouk, A., Brabenec, T. (2020), Improving financial capability: the mediating role of financial behavior, "Economic Research-Ekonomska Istraživanja”, 34 (1), pp. 1265-1282, https://doi.org/10.1080/1331677X.2020.1820362

Dorn, D., Huberman, G. (2005), Talk and action: What individual investors say and what they do, "Review of Finance", 9 (4), pp. 437-481, https://doi.org/10.1007/s106 79-005-4997-z

Driessen, J., Laeven, L. (2007), International portfolio diversification benefits: Cross-country evidence from a local perspective, "Journal of Banking and Finance", 31 (6), pp. 1693-1712, https://doi.org/10.1016/j.jbankfin.2006.11.006

Elton, E.J., Gruber, M.J. (1977), Risk reduction and portfolio size: An analytical solution, “The Journal of Business", 50 (4), pp. 415-437, https://doi.org/10.1086/295964

Errunza, V., Hogan, K., Hung, M.W. (1999), Can the gains from international diversification be achieved without trading abroad?, "The Journal of Finance", 54 (6), pp. 2075-2107, https://doi.org/10.1111/0022-1082.00182

Euronext (2020), Regulated markets (Securities and derivatives) operated by Euronext, https://www.euronext.com/en/regulation (accessed: 21.11.2020).

European Commission (2014), Markets in Financial Instruments (MiFID II) - Directive 2014/65/EU, https://ec.europa.eu/info/law/markets-financial-instruments-mifi d-ii-directive-2014-65-eu_en (accessed: 25.11.2020).

Evans, J.L., Archer, S.H. (1968), Diversification and the reduction of dispersion: An empirical analysis, “The Journal of Finance”, 23 (5), pp. 761-767, https://doi.org/10.11 11/j.1540-6261.1968.tb00315.x

Guidi, F., Gupta, R., Maheshwari, S. (2011), Weak-form market efficiency and calendar anomalies for Eastern Europe equity markets, "Journal of Emerging Market Finance”, 10 (3), pp. 337-389, https://doi.org/10.1177/097265271101000304

Juncker, J.C. (2014), A new start for Europe: My agenda for jobs, growth, fairness, and democratic change, Political guidelines for the next European Commission. Opening Statement in the European Parliament Plenary Session, 36, https://ec.europa.eu /commission/presscorner/detail/en/SPEECH_14_546 (accessed: 18.11.2020). 
Klapper, L., Lusardi, A., Panos, G.A. (2013), Financial literacy and its consequences: Evidence from Russia during the financial crisis, "Journal of Banking and Finance", 37 (10), pp. 3904-3923, https://doi.org/10.1016/j.jbankfin.2013.07.014

Markowitz, H. (1952), Portfolio selection, “The Journal of Finance”, 7 (1), pp. 77-91, https://doi.org/10.1111/j.1540-6261.1952.tb01525.x

Miloş, M.C., Barna, F.M., Boțoc, C. (2020), Multifractal Detrended Fluctuation Analysis (MF-DFA) of Stock Market Indexes. Empirical Evidence from Seven Central and Eastern European Markets, "Sustainability”, 12 (2), https://doi.org/10.3390/su12020535

Moskowitz, T.J., Vissing-Jørgensen, A. (2002), The returns to entrepreneurial investment: A private equity premium puzzle?, "American Economic Review”, 92 (4), pp. 745-778, https://doi.org/10.1257/00028280260344452

Nasdaq Baltic Equity Index (2020), Baltic Market Index Statistics, https://nasdaqbaltic .com/statistics/en/charts (accessed: 10.11.2020).

Nielsson, U. (2009), Stock market merger and liquidity: The case of Euronext, "Journal of Financial Markets”, 12 (2), pp. 229-267, https://doi.org/10.1016/j.finmar.20 08.07.002

Nivet, J.F. (1997), Stock markets in transition: the Warsaw experiment, "Economics of Transition", 5 (1), pp. 171-183, https://doi.org/10.1111/j.1468-0351.1997.tb00009.x

Quaglia, L., Howarth, D., Liebe, M. (2016), The political economy of European capital markets union, "Journal of Common Market Studies”, 54 (51), pp. 185-203, https:// doi.org/10.1111/jcms.12429

SEE link (2020), About us, http://www.see-link.net/about-us/15 (accessed: 15.11.2020).

Statman, M. (1987), How many stocks make a diversified portfolio?, "Journal of Financial and Quantitative Analysis”, 22 (3), pp. 353-363, https://doi.org/10.2307/2330969

Tilfani, O., Ferreira, P., El Boukfaoui, M.Y. (2020), Revisiting stock market integration in Central and Eastern European stock markets with a dynamic analysis, "Post-Communist Economies”, 32 (5), pp. 643-674, https://doi.org/10.1080/14631377.2019.16 78099

Thomson Reuter Eikon Database (2020), Stock price and trade volume data, https://ei kon.thomsonreuters.com/index.html (accessed: 15.11.2020).

Véron, N., Wolff, G.B. (2016), Capital Markets Union: a vision for the long term, "Journal of Financial Regulation”, 2 (1), pp. 130-153, https://doi.org/10.1093/jfr/fjw006

Worthington, A., Higgs, H. (2004), Random walks and market efficiency in European equity markets, “The Global Journal of Finance and Economics”, 1 (1), pp. 59-78, https://eprints.qut.edu.au/2319/ (accessed: 15.11.2020). 


\section{Perspektywy dywersyfikacji jednolitego rynku akcji: analiza na przykładzie wybranych krajów Europy Środkowo-Wschodniej}

Opracowanie przedstawia analizę korzyści płynących z istnienia jednolitego rynku akcji dla ośmiu rynków akcji z Europy Środkowo-Wschodniej w kontekście ryzyka dywersyfikacji. Dla celów analizy każda giełda została potraktowana jako osobny portfel obejmujący spółki notowane w latach 2018-2019. Do identyfikacji ryzyka ośmiu rynków akcji z Europy Środkowo-Wschodniej wykorzystano techniki dywersyfikacji portfela. Wyniki analizy wskazują, że rynkiem akcji o najniższym ryzyku dywersyfikacji była Giełda Bułgarska, następnie Giełda Papierów Wartościowych w Pradze, Giełda Papierów Wartościowych w Lublanie i Giełda Papierów Wartościowych w Zagrzebiu. Portfel zbudowany z akcji Giełdy Papierów Wartościowych w Zagrzebiu niósł ze sobą najwyższe ryzyko portfela, ale jednocześnie oferował również najwyższe tygodniowe średnie ważone zwroty. Rynki akcji, na których doszło do zmniejszenia ryzyka portfelowego w wyniku ujednolicenia, to Giełda Papierów Wartościowych w Bratysławie, Giełda Papierów Wartościowych w Budapeszcie, Giełda Papierów Wartościowych w Bukareszcie, Giełda Papierów Wartościowych w Warszawie i Giełda Papierów Wartościowych w Zagrzebiu. Indeksy, dla których wzrastało ryzyko portfela w momencie ujednolicenia, dotyczą Bułgarskiej Giełdy Papierów Wartościowych, Giełdy Papierów Wartościowych w Lublanie i Giełdy Papierów Wartościowych w Pradze. Z perspektywy zarządzania, inwestujący w instrumenty finansowe zyskują nowe spojrzenie na możliwości dywersyfikacji oferowane w ramach hipotetycznego jednolitego rynku akcji w Europie Środkowo-Wschodniej.

Słowa kluczowe: możliwości dywersyfikacji, rynek giełdowy Europy

Środkowo-Wschodniej, korzyści z ujednolicenia, bilans korzyści i ryzyka

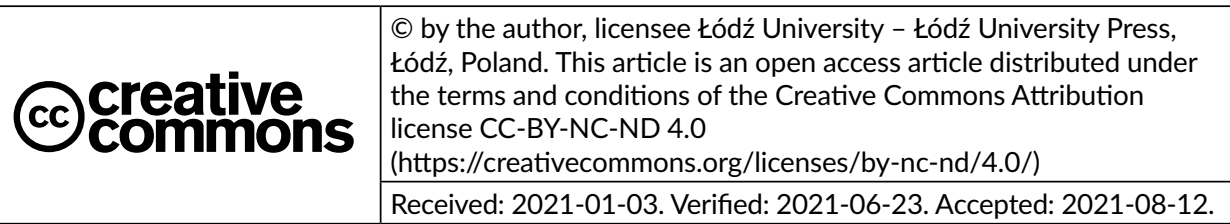

